\title{
Марина Михайлова
}

Поволжская государственная сочиально-гуманитарная академия, кафедра иностранных языков (Россия)

\section{ПРИРОДА НЕВЫРАЗИМОГО И ФЕНОМЕН МОЛЧАНИЯ В РУССКОМ ЯЗЫКЕ И РУССКОЙ КУЛЬТУРЕ}

Объектом настоящего исследования являются семантика невыразимого и феномен молчания в русском языке и русской культуре. Предмет - изучение сопряженного существования семантики невыразимого и феномена молчания в разных исследовательских парадигмах.

Значение невыразимого в русском языке до настоящего времени не было предметом специального исследования. Русисты говорили о нём лишь попутно (Николаева 1984), либо в связи с анализом смежных явлений (Андреев 2007; Горшкова 2005; Иванян 2015). Между тем значение невыразимого - это функционально-семантическая категория, особое значение со своим планом выражения. При этом план выражения представлен системой иерархически организованных языковых единиц.

Литературоведы в XX - начале XXI веков активно изучают значение невыразимого в рамках различных взаимообусловленных оппозиций «речь - молчание», «бытие - инобытие». Значению невыразимого в русском литературоведении посвящён цикл кандидатских диссертаций (Абрамова 2007; Глушкова 2010; Лукинова 2013; Маркова 2005) и др.

В русистике интерес к оппозиции «речь - молчание» усилился в конце XX в. и был ознаменован рядом важных работ (Арутюнова 1994; Богданов 1998; Полянский 1990; Почепцов 1986). Если в конце XX в. изучение феномена молчания лингвистами носило пилотный характер, то в начале XXI в. возрастает число обсуждаемых проблем; сами проблемы всё более дифференцируются и углубляются. Русисты разрабатывают репертуар средств передачи концепта молчания, выявляют «слова молчания», строят типологию культурных смыслов русского молчания (Ковшова 2011: 279; Копылова 2014).

Феномен молчания приобретает междисциплинарный характер исследования, его изучают не только в лингвистике, но и в литературоведении (Эпштейн 2006), психологии, философии (Бибихин 2002), теологии. Ученые 
спорят о первичности и вторичности молчания по отношению к речи, и эта дискуссия приобретает актуальность для многих исследовательских парадигм.

Теологи полагают молчание изначальным состоянием бытия. Неизреченное выступает «как первоначальное состояние Бытия, как характеристика мира в его потенциальности и непроявленности, как безмолвие творческого Духа» (Золотухина-Аболина 2000: 23). В философско-онтологическом аспекте молчание рассматривается как символ «предбытия», «ничто».

Многие лингвисты рассматривают молчание как «отрицательный феномен»: «молчанию предшествует говорение, говорение же необязательно предваряет молчание» (Арутюнова 1994: 106).

Мы преднамеренно остановились на описании некоторых проблем изучения феномена молчания, поскольку круг его вопросов раскрывает и характер проблем изучения семантики невыразимого. Перейдем к собственно предмету исследования - характеристике изучение сопряженного существования семантики невыразимого и феномена молчания в разных исследовательских парадигмах.

I. Онтологическое прочтение феномена молчания указывает на его приоритет в способности обозначить истину, поскольку словами трудно выразить границы сущности. Молчание «лучше отвечает неопределенности мира. Человек - единственное в живой природе говорящее существо, он же и первое молчащее существо. Человеческая речь была бы невозможна без исходного молчания» (Бибихин 2002: 32). Ученые противопоставляют коммуникативно значимое и коммуникативно незначимое молчание. Иными словами, в онтологическом прочтении молчание противопоставляется речи как более выразительное и даже исходное. Что касается семантики невыразимого, то её истоки также находятся в рефлексии противопоставления мира обыденного и инобытия. Поскольку изначально семантика невыразимого как самостоятельное значение языка «обслуживала» сферу чувственно невоспринимаемого, но изначально существующего.

II. В теологическом понимании (особенно в учении молчальников, исихазме) молчание понимается как ближайший путь к Богу. «Молчание - особое состояние духа, отрешившегося от земного начала для того, чтобы услышать голос Истины» (Александрова 2005: 73). Значение невыразимого очень близко к такому пониманию, что особенно ярко проявилось, в частности, в философско-теологической концепции йенских романтиков, в художественной практике русских поэтов-романтиков XIX в. В целом в основе религиозного молчания находится представление об инаковости и сакральности всего божественного (Ковшова 2011: 279-280). Семантика невыразимого первоначально и была языковым воплощением, несовершенным способом передачи совершенного инобытия. Подтверждением сказанному является план выражения семантики невыразимого. Это преимущественно языковые 
единицы с семантикой отрицания (лексемы с отрицательными приставками, внутрилексемное отрицание, отрицательные конструкции).

III. Следствием названного выше противопоставления «речь - молчание», которое коррелирует с противопоставлением «чувственно воспринимаемый мир - мир инаковости», в русском языке является традиция апофатической риторики, пришедшая в Россию вместе с православием. В Новом Завете апостол Павел учит, что драгоценно перед Богом «в нетленной красоте кроткого и молчаливого духа». Следовательно, в основе оппозиций «речь - молчание» и «выражаемое - невыразимое» находится представление о сверхзначимом (сакральном) и запрет на произнесение слов / речи о таковом. В то же время магистральным способом образования эвфемизмов, слов и выражений, формально избегающих запрет на произнесение, является образование номинаций при помощи средств отрицания. Покажем это на примерах из «Этимологического словаря русского языка» М. Фасмера: «Невеста. Лучшей по-прежнему остаётся старая этимология, которая видит здесь первоначальное значение «неизвестная». Табуистическое название должно было защитить женщину, вступающую в чужой для неё дом, дом её жениха, от злых духов» (Фасмер 1971: 54). Ср.: «Невод. Возможно, из vod* с отрицанием по мотивам табу, чтобы рыбы не узнали опасного для них приспособления» (Фасмер 1971: 55).

Таким образом, противопоставления «молчание - речь», «выражаемое - невыразимое», репрезентируемые в апофатической риторике, проявляются и в коммуникативном аспекте. При этом в коммуникативном (семиотическом) аспекте молчание понимается как знак особого рода (Почепцов 1986). С другой стороны, семантика невыразимого - есть способ формально избежать запрет на произнесение при помощи отрицания. По свидетельству Д. К. Зеленина, хозяйки, чтобы избежать запрета пересчитывать испечённый хлеб, употребляли при счёте отрицание: «не один, не два, не три» (Зеленин 1929). К средствам апофатической риторики по происхождению относятся ставшие мёртвыми метафорами устойчивые сочетания красота неписанная; свет несказанный; названные языковые средства являются способом передачи значения невыразимого в русском языке.

Обращение к плану выражения семантики невыразимого в русской романтической картине мира подтверждает сказанное выше: мотив невыразимого в творчестве поэтов-романтиков В. А. Жуковского, Ф. И. Тютчева, А. А. Фета и др. передаётся при помощи апофатической риторики: риторических отрицаний, риторических вопросов, соотносимых по семантике с отрицанием, отрицательных конструкций, словообразовательных средств отрицания, неопределенных сравнений в понимании И. Б. Голуб (Голуб 2001).

С наибольшей очевидностью сопряженное сосуществование семантики невыразимого и апофатической риторики проявляется в русской художественной литературе: в фольклорных текстах (ни в сказке сказать, ни пером опи- 
сать; красота неписанная; свет несказанный), в классике русской литературы, см., напр. (Гончаров 1997), в литературе постмодернизма (Гаврилова 2009).

В дальнейшей истории развития феномена молчания и семантики невыразимого в русском дискурсе шло размежевание специализации этих значений. Многие средства семантики невыразимого стали терять связь с полем сакрального, иномирного и начали просто выражать «запредельно высокое качество». Примером сказанного являются, в частности, неопределенные сравнения типа ни в сказке сказать, ни пером описать или не расскажешь, не опишешь, что за жизнь (...). В подобных сравнениях даётся высшая оценка описываемого, не получающая однако конкретного образного выражения (Голуб 2001).

Значение «запредельно высокого качества» активно в составе средств передачи семантики невыразимого. См., как носители современного русского языка синонимически выражают семантику невыразимого. [На сайте mail. ru задаются вопросы, на которые читатели-пользователи дают ответы, потом обсуждают и называют лучший. Семь лет назад был предложен вопрос:]

Чё такое красота неписанная?

Үиз Просветленный (44280), Вопрос закрыт 7 лет назад http://otvet.mail.ru/ question/6519285

ООО „Аспэг” Гуру (3086) 7 лет назад

Это когда слов нет и челюсть с пола поднимать приходится.

Не принимая во внимание гиперболическую иронию ответа, заметим, что на вопрос о ключевом эпитете семантики невыразимого, респондент приводит пример другого средства выражения категории невыразимого (слов нет) и далее ответ уточняется иронической перифразой, описательно передающей значение «запредельно высокого качества».

Анализируя семантические доминанты русской языковой картины мира, учёные называют среди прочих значение предела (Петрухина 2003: 431). Полагаем, что функционально-семантическая категория невыразимого имеет зону пересечения со значением предела. При десемантизации плана выражения сакрального, описания табуированного инобытия средства его выражения «переходят» в мир профанного и начинают передавать в современном русском дискурсе значение «запредельно высокого качества»; ср. с вышеприведённым ироническим примером (челюсть с пола поднимать приходится - так описывается запредельное изумление запредельно высоким качеством, изумление красотой). Таким образом, далеко не все средства выражения семантики невыразимого напрямую связаны с описанием / выражением сакрального, инобытия.

Попутно заметим, что и сама апофатическая риторика с её магистральным приёмом номинации при помощи отрицания планом содержания имеет возвышенно-сакральное. 
Обращение к словарю М. Фасмера показывает, что при помощи приёма апофатической риторики активно образуются не только номинации возвышенно-сакрального содержания, но и, в частности, табуизмы, например: «Недра «лихорадка», архангельское. Вероятно, это название, преследующее цель предотвратить заболевание, образовано из не и драть. Ср. трясавица - то же, архангельское, от трясти» (Фасмер 1971: 58).

IV. Соотношение оппозиций «речь - молчание» и «выражаемое - невыразимое» можно проследить и в культурологическом аспекте. «В русской культуре тишина обозначает отсутствие шума повседневной жизни, что не означает полного беззвучия: исчезновение шума помогает услышать едва уловимое дыхание природы, например, в пейзажах природы, лирических миниатюрах М. Пришвина и В. Солоухина» (Мухаметов 2012: 80). Феномен молчания сравнивают с русской иконописью, лишенной драматического действия, создающей образ вечного созерцания. В целом молчание учёные называют константой русской культуры, репрезентированной в языковой картине мира (Копылова 2014: 38). С другой стороны, феномен невыразимого в искусстве современные ученые предлагают понимать как ауру недовоплощённых возможностей. Невыразимое «лишь реет, угадывается, как облаком или аурой окутывает материю, одухотворяя её чувственным сгустком состояний, мыслей, представлений, предчувствий художника, которых он сам довольно часто не осознаёт, рождает и выражает интуитивно (Синцов 2003: 27, 3). Е. В. Синцов исследует природу невыразимого как явленость в орнаментальных формах, изучает орнамент в прикладном искусстве, музыке. Анализируя татарский прикладной орнамент, ученый замечает, что образы орнамента - всегда инобытие природных форм.

При таком понимании природа невыразимого является синонимом феномена молчания, изучаемого в других исследовательских парадигмах филологами.

Осуществленное нами сопоставление природы невыразимого и феномена молчания позволяет сделать следующие выводы: 1) семантика невыразимого в русском языке является самостоятельным значением с обширным планом выражения, представленном на разных уровнях языка, репрезентируется языковыми единицами, иерархически организованными в систему; 2) природа невыразимого и феномен молчания привлекли внимание исследователей только в конце XX в.; оба понятия имеют значительную зону пересечения, сопоставление истории их изучения в разных исследовательских парадигмах выявляет сущностные характеристики категории невыразимого; 3) в философско-онтологическом аспекте молчание многими исследователями ставится превыше речи, сходная картина наблюдается и в характеристике семантики невыразимого; 4) в теологическом аспекте молчание и семантика невыразимого первоначально репрезентировали инаковое, сакрально божественное; 5) магистральным приёмом выражения инакового, сакрально божественного - приёмом апофатической риторики - было отрицание (словообразовательное, внутри- 
лексемное, синтаксическое); 6) в основе сопряжённых оппозиций «речь - молчание», «выражаемое - невыразимое» лежит табу, запрет на произнесение; в дальнейшем развитии плана передачи семантики невыразимого происходит «переход» средств выражения из зоны возвышенно сакрального в зону профанного; 7) феномен молчания и природа сакрального в культурологическом аспекте изучения проявляются как синонимы, как константы русской культуры.

\section{Библиография}

Абрамова В. И. (2007), Мотив «невыразимого» в русской романтической картине мира: oт В. А. Жуковского к К. К. Случевскому, «Диссертация ... кандидата филологических наук», Москва, 233 с.

Александрова И. Б. (2005), Слово о молчании, «Русская речь», №4, с. 70-75.

Андреев В. В. (2007), Средства выражения семантики умолчания в произведениях 3. Н. Гиппиус, «Автореферат диссертации ... кандидата филологических наук», Самара, 184 с.

Арутюнова Н. Д. (1994), Молчание: контексты употребления, «Логический анализ языка. Язык речевых действий», Москва, с. 106-117.

Бибихин В. В. (2002), Язык философии, Москва, 416 с.

Богданов К. А. (1998), Очерки по антропологии молчания. Ното Tacens, Санкт-Петербург, 352 с. Гаврилова М. В. (2009), Никто, Ничто и Кто Угодно: «апофатика» Ю. Буйды, «Логический анализ языка. Ассерция и негация», Москва, с. 297-305.

Глушкова М. А. (2009), «Нездешнее» Владимира Соловьева и «Невыразимое» Афанасия Фета «Вестник Нижегородского университета им. Н. И. Лобачевского», №6, с. 32-36.

Голуб И. Б. (2001), Стилистика русского языка, Москва, 441 с.

Гончаров С. А. (1997), Творчество Гоголя в религиозно-мистическом контексте, Санкт-Петербург, $340 \mathrm{c}$.

Горшкова Л. А. (2005), Семантика и функиии неопределенных местоимений в прозе Б. К. Зайцева: «Диссертация ... кандидата филологических наук», Уфа, 186 с.

Зеленин Д. К. (1929), Табу слов у народов Восточной Европы и Северной Азии, Часть первая, Запреты на охоте и других промыслах, «Сборник музея антропологии и этнографии», том 8, Ленинград, с. 88-144.

Золотухина-Аболина Е. В. (2000), Смысл молчания, «Научная мысль Кавказа», №3, с. 22-27.

Иванян Е. П. (2015), Семантика умолчания и средства её выражения в русском языке, Москва, 307 с.; 2-е издание.

Ковшова М. Л. (2011), Пауза, молчание и тишина в пьесах М. Булгакова, «Логический анализ языка. Адресация дискурса», Москва, с. 276-293.

Копылова Т. Р. (2014), Молчание в современной лингвистике: подходы к анализу, «Вестник Удмуртского университета», №5 (2), с. 36-39.

Лукинова А. Р. (2013), Мотивно-тематический аспект эволюиии лирики А. А.Фета (образ звезды), «Диссертация ... кандидата филологических наук», Санкт-Петербург, 234 с.

Маркова В. В. (2005), Поэтика безмолвия в русской литературе 1820-1840 годов (от «невыразимого» В. А. Жуковского к «Мёртвым душам» Н. В. Гоголя, «Автореферат диссертации ... кандидата филологических наук», Тюмень, 16 с.

Мухаметов Д. Б. (2012), Молчание как компонент русской культуры, «Вестник Нижегородского университета им. Н. И. Лобачевского», №2, с. 77-82.

Николаева Т. М. (1985), Функици частии в высказывании (на материале славянских языков), Москва, 169 с. 
Петрухина Е. В. (2003), Доминантные черты русской языковой картины мира (в сравнении с чешской), «Русское слово в мировой культуре. Материалы Х Конгресса Международной ассоциации преподавателей русского языка и литературы», Санкт-Петербург, с. 426-432.

Полянский А. Н. (1990), Формы и функции неизреченного в текстах художественной литеpaтуры, «Филологические науки», №2, с. 54-62.

Почепцов Г. Г. (1986), Молчание как знак, «Анализ знаковых систем: История логики и методологии науки», Киев, с. 90-91.

Синцов Е. В. (2003), Природа невыразимого в искусстве и культуре, Казань, 304 с.

Фасмер М. (1971), Этимологический словарь русского языка, том III, 827 с.

Эпштейн М. Н. (2006), Слово и молчание: Метафизика русской литературы, Москва, 559 с.

Marina Michajlova

\section{THE NATURE OF INEXPRESSIBLE AND SILENCE PHENOMENON IN RUSSIAN LANGUAGE AND THE RUSSIAN CULTURE}

(Summary)

The interfaced existence of inexpressible semantics and silence phenomenon in different research paradigms is investigated in the article: philosophical, theological, literary, culturological, apophatic rhetoric, cognitive linguistics and euphemisms theory. The main units' formation method of inexpressible category and apophatic rhetoric - denying (word-formation, inside the lexical item, syntactic, rhetorical, that is with the shift of the contents plan and expression plan) is shown in the article. Everything told in the article is illustrated by examples from M. Fasmer's dictionary and modern Internet communications.

Keywords: inexpressible, silence phenomenon.

Марина Михайлова

\section{ПРИРОДА НЕВЫРАЗИМОГО И ФЕНОМЕН МОЛЧАНИЯ В РУССКОМ ЯЗЫКЕ И РУССКОЙ КУЛЬТУРЕ}

(Резюме)

В статье исследовано сопряженное существование семантики невыразимого и феномена молчания в разных исследовательских парадигмах: философской, теологической, литературоведческой, культурологической, а также апофатической риторики, когнитивной лингвистики и теории эвфемии. В работе назван магистральный приём образования единиц категории невыразимого и апофатической риторики - отрицание (словообразовательное, внутрилексемное, синтаксическое, риторическое, то есть со сдвигом плана содержания и плана выражения). Сказанное иллюстрируется примерами из словаря М. Фасмера и современных интернет-коммуникаций.

Ключевые слова: невыразимое, феномен молчания. 